Notre Dame Law Review

Volume 23 | Issue 1

Article 3

$11-1-1947$

\title{
Anonymous Treatise on Law: The Pseudo-Platonic Dialogue Minos
}

Anton-Hermann Chroust

Follow this and additional works at: http://scholarship.law.nd.edu/ndlr

Part of the Law Commons

\section{Recommended Citation}

Anton-Hermann Chroust, Anonymous Treatise on Law: The Pseudo-Platonic Dialogue Minos, 23 Notre Dame L. Rev. 47 (1947). Available at: http://scholarship.law.nd.edu/ndlr/vol23/iss1/3

This Article is brought to you for free and open access by NDLScholarship. It has been accepted for inclusion in Notre Dame Law Review by an authorized administrator of NDLScholarship. For more information, please contact lawdr@nd.edu. 


\section{AN ANONYMOUS TREATISE ON LAW: THE PSEUDO-PLATONIC DIALOGUE MINOS}

Among the many smaller writings which at one time or another have been attributed to Plato, we possess a short dialogue entitled Minos. ${ }^{1}$ Although this work is not entirely unworthy of Plato, there exists today little doubt among competent classical scholars that it is an excellent imitation of Plato's early style and technique by one of his last disciples whose name is unknown to us. ${ }^{2}$ From all appearances we may safely assume that the Minos was composed shortly after the completion of Plato's Laws (Nomoi). ${ }^{3}$ The anonymous author of the Minos makes full use of the History of Euphorus ${ }^{4}$ who maintains the thesis that the laws promulgated by the famous Spartan law-giver Lycurgus ${ }^{5}$ were derived from Crete, or to be more exact, from the fabulous King Minos.; Plato, on the other hand, in his genuine

1 The Neo-Platonist Thrasyllus, who wrote during the reign of Emperor Tiberius (14-37 A. D.), included the Minos among the genuine works of Plato. See his Tetralogies IX; Compare also Diogenes Laertius III, 57.

2 The first to point out in a truly scholarly manner the fact that the Minos could not possibly be a genuine dialogue of Plato is Boeckh, A., in his In Platonis qui vulgo fertur Minoem, Halle a/S., 1807. Boeckh's arguments are so weighty that they preclude any possibility of attributing the Minos to Plato himself. On the other hand, we are unable to assign the Minos to any particular author, although we are justified in assuming that the anonymous author is one of the disciples of Plato who was thoroughly familiar with Plato's early style and who displays an astonishing grasp of Platonic thought.

3 The Laws can be dated with reasonable accuracy. Plato died 348/347. The Laws were published posthumously, that is, after 348/347. Now Isocrates in his Philip, published in 346, refers both to Plato's Republic and Laws. Hence the Laws must have been published in $347 / 346$.

4 See Jacoby, F. Die Fragmente der Griechischen Historiker II A, p. 94, frag. 174 and frag. 149.

5 It is now commonly held that Lycurgus or Lyco-vorgas ("Wolf-repeller") was not a historical figure, but rather an Arcadian deity or "hero" who was worshipped by the Arcadian shepherds as the protector of their flocks. Herodotus $(I, 65)$ himself seems to debate whether Lycurgus was a god or a man when he quotes a Delphic oracle:

"Welcome, Lycurgus, come to my rich shrine,

Whom Zeus loves well, and all celestials love;

Shall I declare thee human or divine?"

( There is a difficulty about King Minos of Crete. In Homer he appears as an Achean ruler in Crete-and not as a Cretan-two generations before the Trojan War; that is, about the middle of the thirteenth century B. C. It was 
dialogue Laws does not accept this theory ${ }^{7}$ which had already been mentioned by Herodotus. ${ }^{8}$

Irrespective of the fact that the Minos is definitely not the work of Plato, it is nevertheless one of the most important philosophical treatises on law in that it definitely marks the beginning of what we would call legal philosophy in the narrower sense of the term. In order to understand the scope of the Minos we will have to keep in mind that this dialogue resumes the discussion about the nature of law which had been taken up in the first book of the Laws $^{\circ}$

held by some Greek writers in later times that there were actually two Cretan kings of that name, of whom the earlier reigned towards the end of the fifteenth century B. C. This view finds some support in Homer himself. See Iliad XIV, 321 , as against Odyssey $\mathrm{XI}, 322$, and Odyssey XIX,179. Hence it is quite possible that Minos I., the "Destroyer," was the leader of some Achaean invaders who conquered Crete, destroyed the cities of Phaestus and Hagia Triada in 1406 (?), and made Cnossus their capital. This Minos would also be the founder of the Creta-Achaean thalassocracy (rule of the sea), famous in later Greek tradition. Minos II., on the other hand, might have been the leader of a band of Achaean and Carian raiders who invaded the Nile delta and were repelled by Pharao Merenptah in 1229 B. C. This Minos II. is probably the king to whom Homer is referring. Herodotus, however, erroneousiy made Minos I. and Minos II. into one king (I,171; I,173; III,122). Homer (Odyssey XIX,160) also mentions the fact that in Crete "there dwelled Cydonians, Dorians of three tribes, and proud Pelasgians," insinuating thereby that Crete had been conquered by peoples from the Greek mainland. As to the name "Pelasgians," see Plutarch, Pyrrhus 1: "Of the Thesprotians and Molossians after the great flood, the first king ... was Phaeton .. . who came into Epirus with Pelasgus." The Pelasgians are, therefore, the descendants of Pelasgus. The various attempts to explain the word Pelasgiansthose are the original dwellers in Greece-by linking it to the Greek word pelargos (the stork), are plain nonsense.

7 Laws 624 ". . . among us Cretans he (scil., the author of the law) is said to have been Zeus, but in Lacedaemon . . . they say that Apollo is their lawgiver ..."

8 Herodotus I,65. It seems, however, that the stronger argument of Ephorus in favor of the Cretan origin of Lycurgus' laws was necessary to convince the Greeks, in particular the author of the Minos as well as Aristotle who fully accepted the story that the Spartan laws originally came from Crete. See Aristotle, Politics 1271 b 20 ff.; particularly 1271 b 24: "According to tradition, Lycurgus ... went abroad and spent most of his time in Crete."

9 Plato, Laws 644D: ". . . there is reflection about the good and evil of them (scil., the laws) ... And this, when embodied in a decree by the state, is called law ... May we not conceive each of us living beings to be a puppet of the gods ... created with a purpose . . . We know that ... affections within us are like cords and strings, which pull us in different directions and opposite ways, and to opposite actions: And herein lies the difference between virtue and vice . . . There is one among these cords which every man should take hold of and never let go .... and this is the sacred and golden cord of reason, called by us the common law of the state. There are other cords which are hard and of iron, but 
without, however, achieving any conclusive results. Hence in the Minos the same question concerning the nature or essence of the law is being reformulated once again by contrasting the positive or man-made law with "philosophy," that is to say, with the rational natural law. A student, who discusses this problem with Socrates, begins first by defining law in general as being that which is prescribed or commanded by a politically organized society. ${ }^{10}$ Socrates counters by pointing out the fundamental error of this one-sided definition. For sight, Socrates insists, is not identical with that which is seen, but basically different from the latter. Hence "reason" (logos) cannot be that which is actually being said (tá legomena), but something essentially beyond this. In the further development of this argument Socrates introduces the concept of the techné, the art of right thinking which in Plato's system plays an all-important role. Techne, we are told, consists in the discovery of the real thing, the pragma, or, as we would put it, true being. ${ }^{11}$ The student, however, is still under the impression that Socrates is referring to the actual "positive" laws and enacted ordinances of a given politically organized society and hence volunteers a second definition of law which sees in the latter a dogma poleos, ${ }^{12}$ that is to say, the concrete instrumentality or rule of a given State.

this one is soft because it is golden ... Now we ought always to cooperate with the lead of the best, which is law. For inasmuch as reason is beautiful and gentle, and not violent, her rule of necessity must have ministers in order to help the golden principle in conquering the other principles. And thus the moral of the tale about our being puppets will not have been lost, and the meaning of the expression 'superior or inferior to a man's self' will become clearer. And the individual, attaining to right reason in this matter of pulling. the strings of the puppet should live according to its rule; while the state, receiving the same from some god or from one who has knowledge of these things, should embody it in a law, to be its guide in its dealings with itself and with other states. In this fashion virtue and vice will be more clearly distinguished by us. And when they have become clearer, education and other institutions will in like manner become clearer ...."
10 Minos 313B.
11 Minos 314B.
12 Minos 314BC. 
This second definition of the student makes it quite clear that the latter conceives of law only in terms of man-made laws, and that he believes law to be but the sum total of enforced human enactments. Socrates, on the other hand, attempts to point out that in order to grasp the full significance of the term "law" one has to go beyond the fact that it also happens to be something which is valid because it is or might be enforced by the State. ${ }^{13}$ Thus he proposes that the true meaning of the law should be understood in terms and in relation to objective value, that is to say, in terms of objective good or objective evil. ${ }^{14}$ A "true" law, according to Socrates, of necessity must always have something truly and objectively good for its object and end. And this objective good is real and exists in the State. True law, therefore, is actually nothing else than the discovery of something truly good and really existing; in other words, it must be related to being $q u a$ being. Positive law, on the other hand, may be either good or bad, useful or harmful for society. Hence it cannot be "true" law in the strict sense of the term, lacking this necessary ordination to the absolute and objective good. ${ }^{15}$

The main argument of Socrates, therefore, is that "true" law is always related to the nature of reality, and that justice signifies harmony with true being. ${ }^{16}$ Hence the authority of law depends on its relation to being, a statement which on the main but reiterates a basic Greek assumption that the law is the clue to the very nature of things, in other words,

13 This is an old problem which had already been discussed rather thoroughly by the Sophists. The real question with which they were faced was whether above and beyond individual opinion there is anything whatever that could be called absolute right and just.

14 Minos 314Dff.

15 Minos 315A.

16 Among the early Greek thinkers we are able to discern two basic presuppositions which are being considered self-evident. The first is concerned with the validity of the law, the second with the assertion that obedience to the law is of advantage. The naive mind obeys the laws without asking whence they come or by what they are justified. The laws actually exist; they are here once for all, and the individual has to abide by them. None of the Pre-Sophistic thinkers thought of examining these laws or of asking in what their claim to validity consists. 
declaratory of true being. The truth which law reveals is the knowledge and understanding of being. ${ }^{17}$ In the Minos we are once more confronted with the same problem. For if we are told here that true law consists in discovering true and real being (exeuresis ontos), then this assertion simply implies that all true law must be just law. For justice in its ultimate significance is synonymous with true reality and objective being. This idea of justice is at the basis of all classical Greek legal thought and legal philosophy.

Admittedly, man-made laws change in time and are different in different places, ${ }^{18}$ a fact which is not being denied by Socrates. ${ }^{19}$ But, interposes Socrates, the "good" as such is always the same and, therefore, really "is." And the good, being real, is always the same and, hence, unchangeable. The man-made law should have for its sole object the "good," that is to say, that which always is, and not that which is not, namely evil. By failing to make the real and true good its object any man-made law misses that which is truly "legal" in the higher sense of true law. ${ }^{20}$ "Legal," there-

17 This idea, which might be called a classical expression of early Greek thought, was first expressed by Parmenides. See Diels, H. Die Fragmente der Vorsokratiker, frag. 1,28 .

18 Minos 315Bff.

19 During the period of Sophistic speculation law became a subject of devious philosophical discussion. The citizens of republican states became accustomed to reflect and decide upon the grounds and validity of the laws, and by doing so they actually put themselves and their personal opinions and views above the law, at least in their judgments. Besides noting these frequent changes of laws or legal enactments, attention also became focused on the great variety of laws exhibited not only in the various legal systems of the different states and nations, but also in the usages found among different peoples. In consequence it was held that the principle of universal validity for all men, times, and places could no longer be attributed to the laws, at least the man-made laws.

In the face of all these problems the serious question arose whether there is anything whatever that could be called valid everywhere and always, a law, that is to say, which is completely independent of the differences between peoples, states, and times and thus authoritative for all. The real issue, therefore, was whether there is such a thing as a law determined by the unchanging nature and order of things (physis); whether there is a law exalted above all mutations and all differences, contrasted by the ever changing features of human legal institutions and the man-made laws. This contrast between nature and institution, natural low and positive law is undoubtedly the most characteristic achievement of the Sopbistic period.

20 Minos 316B. 
fore, is that which is right and just in the sense of being related to the innermost nature of being, to the eternal order of things which stands for eternal justice. True law being always based upon that which truly is, is therefore valid for all of mankind. ${ }^{21}$ True law, like true being, is never subject to change. For the objective good is immutable.

Pressed for an answer as to how we are able to arrive at such a true law, Socrates can only give an allegorical answer which, however, is of deep significance: ${ }^{22}$ All true law comes from God or, as Heracleitus of Ephesus had put it, "all human laws derive their substance from that one law which is of God." ${ }^{23}$ Hence Socrates introduces the mystical personality of King Minos of Crete, ${ }^{24}$ the oldest and most venerable law-giver of ancient Greece. This Minos is said to have derived his wisdom directly from Zeus with whom, according to the testimony of Homer, ${ }^{25}$ he has had intellectual conversation for nine years. ${ }^{26}$ During these nine years Zeus conferred upon him divine wisdom, in other words, that type of wisdom which is necessary in order to understand the true nature of being and the true essence of true law. ${ }^{27}$ Hence

21 Minos 316D.

22 Minos 319Bff.

23 Diels, op. cit., Heracleitus frag. 114.

24 See note 6, supra; Obviously, King Minos to whom Socrates is referring here, is only in name identical with the two historical Creto-Achaean kings mentioned in note 6.

25 Homer, Iliad XIX, 178: “. . . where the monarch Minos dwelled, he who had at every nine years' end conversed with Zeus almighty ..."

26 This anonymous author of the Minos correctly translates this Homeric passage as meaning "intellectual intercourse with Zeus" and not, as most people interpreted it, as signifying carousing and merry-making.

27 Minos 319 Cff. The idea that the human law-giver has received the law from the gods is a very ancient notion. The Louvre, for instance, possesses a sculptural relief of the Babylonian king Hammurabi receiving his famous code of law from the sun god Marduk (about 2000 B. C.). Another famous example is found in Plato's dialogue Gorgias 322C ff.: ". . . the desire of self-preservation gathered men into cities. But when they were.gathered together, having no art of government, they evil intreated one another, and were again in the process of dissolution and destruction. Zeus feared that the entire human race would be exterminated, and so he sent Hermes to them, bringing to them a sense of restraint (aidos) and a feeling for what is right and just (dike) to be the contolling principles of states ... Hermes asked Zeus how he should impart this eidos and dike 
when the anonymous author of the Minos quotes the famous line from Hesiod where King Minos is said to have "the scepter of Zeus," he merely tries, by the use of allegory, to convey the notion that King Minos had been endowed with divine wisdom. ${ }^{28}$ Under the skillful interpretation of Socrates the scepter of Zeus, this age-old symbol of justice, is transformed into the knowledge and undertanding of that which truly is in an objective sense. And law, true law, is nothing else than the eternal truth of that which really is. ${ }^{20}$ All knowledge and understanding of objective reality, however, also pre-supposes a knowledge and understanding of that which is objectively good. But such knowledge is not mere experience or personal opinion; it is techné the art of right thinking and correct reasoning which starts from true being and has as its final object true being. Such knowledge also comprises the practical realization of the good, a realization, that is, which must be the practice of true justice and the things that are right. In order to practice true justice in the administration of the State, the law-giver stands in need of a higher, a philosophical education..$^{30}$ And this philosophical education, again, has to be based on a knowledge which in its ultimate foundations is divine. ${ }^{31}$

Anton-Hermann Chroust

... to a favored few only ... or . . . to all men? To all, Zeus replied, for I should like them all to have a share. For states cannot exist, if a few only share in the virtues. ...."

28 Minos 320D. Hesiod, who in this differs from Homer, conceives Zeus as being the embodiment of justice. All justice is, therefore, directly from Zeus. In this fashion justice receives a definite and commanding position in the divine order of things. Zeus gave justice (dike), that is, a sense of what is right and just, because it "is the supreme good of life." Hesiod, Works and Days 276 ff.

29 Minos 321B.

80 Minos 321C. This passage reminds us of the famous exhortation of Plato: "Until philosophers are kings, or the kings and princes of this earth have the spirit and power of philosophy, and political greatness and philosophical wisdom meet in one . . . cities will never bave rest from their evils-no, nor the human race ..." Republic 473C. Compare also ibid. 487E: ". . . cities will not cease from evil until philosophers rule in them ..." ibid. 501E ff.; $540 \mathrm{~A}$ ff.; $543 ; 592$.

31 Minos 322A. 